\title{
Biomass Estimation Using ALOS PALSAR for Identification of Lowland Forest Transition Ecosystem in Jambi Province
}

\author{
Eva Achmad ${ }^{*}$, I Nengah Surati Jaya ${ }^{2}$, Muhammad Buce Saleh ${ }^{2}$, Budi Kuncahyo ${ }^{2}$ \\ ${ }^{1}$ Graduate School of Bogor Agricultural University, Dramaga Main Road, Campus IPB Dramaga, Bogor 16680, Indonesia \\ ${ }^{2}$ Department of Forest Management, Faculty of Forestry, Bogor Agricultural University, Academic Ring Road, Campus IPB \\ Dramaga, Bogor 16680, Indonesia
}

Received May 14, 2013/Accepted July 29, 2013

\begin{abstract}
The accurate information derived from high accuracy of remote sensing imagery analyses coupled with field observation data are required to develop a sound forest management. The study is mainly emphasized on assessment of the capabilities of remote sensing imageries to identify ecosystem types within the transitional ecosystem. Since, the predominant transition ecosystems found within the study area were secondary forest, rubber jungle, rubber, oil palm plantation, and also other land cover such as mixed plantation and shrubs, therefore, the models developed were focused for those ecosystem types. Prior to any further analysis, this study was initiated to develop the biomass estimation model using $50 \mathrm{~m}$ resolution of ALOS PALSAR image in transition ecosystem, Jambi Province. Biomass models were developed by analyzing the relationship between backscatter magnitude and field biomass. Backscatter magnitude from 1 polarization images, namely $\mathrm{HH}, \mathrm{HV}$, and one additional band of ratio of $\mathrm{HH} / \mathrm{HV}$ were analyzed simultaneously with field biomass. The best models established are $A G B=42,069 \exp (0.510 \mathrm{HV})$ and $A G B=1,610 \exp \left(-0.02 \mathrm{HV}^{2}\right)$ with $R^{2}$ of $52.3 \%$ and $50,8 \%$, respectively. The models are then used to map out the biomass distribution within the transition ecosystem and to identify the factors affecting the magnitude of biomass content for all transition ecosystem types.
\end{abstract}

Keywords: ALOS PALSAR, backscatter, biomass, transition ecosystem

*Correspondence author, email: evaachmad2002@yahoo.com, telp.+62-813-6659-1660

\section{Introduction}

Deforestation in tropical forest has been identified by International Panel on Climate Change as the main source of green house gasses emission (IPCC 2006). To avoid or to reduce deforestation, stakeholders must recognize the driving factors of deforestation (Geist \& Lambin 2001). Deforestation could be caused by natural disturbances and ecosystem processes as well as human civilization, however, has greater impact than that of natural disturbances and ecosystem processes (Zeledon \& Kelly 2009). One example of natural disturbance causing deforestation was the peat swamp forest fire in Jambi Province in 1997 due to el Nino effect. The human factors or anthropogenic factors affecting deforestation can be identified as a result of human activities related to landuse such as, agricultural and plantation, mining, and others (Chambers et al. 2007).

Deforestastion in Jambi Province in 2012 was 76,522.7 ha year ${ }^{-1}$ (MoF 2012). Deforestation occured in the last two decades mainly triggered by the following factors: forest utilization (IUPHHK-HA), mining, transmigration, plantation and forest encroachment. Furthermore, the forest land tend to be converted into oil palm plantation (Abdullah 2010).

To identify deforestation and forest degradation, the approach of carbon content measurement and its temporal changes over certain areas was applied. Forest carbon is quantified by its forest biomass. Biomass is defined as the total amount of tree organic matter above ground, including leaves, twigs, branches, main stem, and bark, and are expressed in dry-oven weight of tones per unit area (Brown et al.1995). Biomass is an important measure for assessing changes in forest structure. According to Jaya et al. (2013), forest biomass distribution depends on its forest ecosystem type. Biomass estimation is a big challenge in tropical forestry research due to the biodiversity and the variation of forest types (Elias \& Wistara 2009).

Biomass information can be obtained by terrestrial through destructive and non destructive field survey, and also by aerial using remote sensing technology both active and passive. Terrestrial biomass calculation can provide accurate data but less efficient because of time consuming, high cost, and very difficult in remote or less accessible location (Clark et al. 2001; Wang et al. 2003; Chen et al. 2004; Lu 2006). In contrast, remote sensing is considered reliable in providing information and relatively low cost. Remote sensing techniques coupled with inventory data are potential to solve the obstacles of direct measurement of biomass (Houghton et al. 2001; Lu 2005; Lu 2006). 
Passive remote sensing such as Landsat TM, has been applied widely to estimate biomass. Steininger (2000) used Landsat TM coupled with field data to estimate biomass of regenerating secondary forest in Bolivia and Brazil. Foody et al. (2003) applied Landsat TM to estimate biomass of dense tropical forest in Brazil, and of logged over forests in Malaysia and Thailand, meanwhile, Lu et al. (2004) used Landsat TM to estimate biomass of secondary forest in Brazilian Amazon. The approach in estimating biomass from Landsat TM was mainly based on its spectral characteristics such as vegetation indices and image transform. Radar remote sensing has advantages to estimate biomass due to cloud existence problem.

ALOS PALSAR one of radar imagery has been examined to assess above ground biomass (AGB) in Indonesia and other tropical countries (JICA-FAHUTAN IPB 2011). Application of ALOS PALSAR in estimating above ground biomass in Indonesia are quite numerous. Jaya et al. (2013) modelled the AGB of dryland tropical forest in Central Kalimantan. Basuki (2012) has found the potential use of fusion between ALOS PALSAR and Landsat TM imageries in order to improve the accuracy of AGB model developed in Labanan Dipterocarp forest in East Kalimantan. Wijaya (2010) also examined the use of ALOS PALSAR to develop the biomass model of tropical forest in East Kalimantan.

In this study, the method to develop accurate and simple biomass estimation model was performed. The models are particularly dedicated for the transition ecosystem types of lowland forest in Muaro Jambi and Batanghari Regency in Jambi Province using ALOS PALSAR. Field data to develop model were collected from transition ecosystem types, namely, secondary forest, jungle rubber, rubber, and oil palm plantation. Biomass distribution derived from estimation model then could be used to identify transition ecosystem in study area.

The main objective of this paper is to develop estimation model of biomass using ALOS PALSAR $50 \mathrm{~m}$ resolution and to assess the capabilities of biomass-based identification of transition ecosystems. The output of this research would then

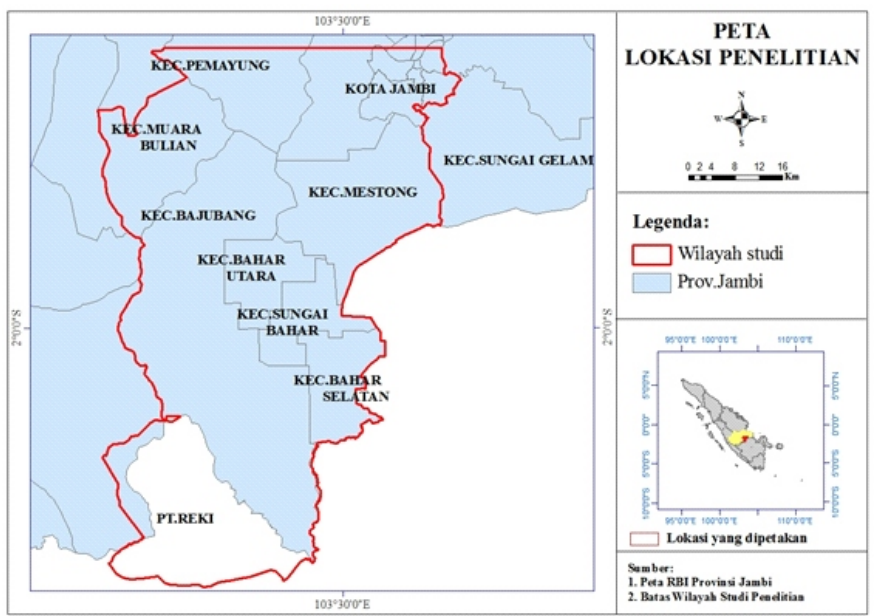

be used to support identification of transition ecosystem types in lowland forest in Jambi Province.

\section{Methods}

There were 4 types of transition ecosystems in this study namely secondary forest, rubber agroforest (jungle rubber), rubber plantation, and oil palm plantation. Secondary forest located in PT. REKI (Harapan rainforest), is a specific purpose concession for forest restoration of which previously managed by PT. Asialog. Jungle rubber as well as rubber and oil palm plantation are predominantly located surrounding Harapan rainforest towards Jambi City, Jambi Province. The study sites belong into 2 regencies, Batanghari and Muaro Jambi Regencies. Study area and distribution of sample plots over transition ecosystems is presented in Figure 1. Field data collection was conducted June 2012-March 2013 and data processing took place in Laboratory of GIS and Remote Sensing, Faculty of Forestry Bogor Agricultural University.

Material used in this study is primary data taken directly from field and ALOS PALSAR imagery with acquisition year 2009. There were 2 shapes of the plots used in this study, the first was rectangular plot for secondary forest and jungle rubber with the size of $20 \times 125 \mathrm{~m}$, and the second was circular plot for rubber and oil palm plantation with certain radius depend on the age of planting. The radius of plot was $17.85 \mathrm{~m}$ for old crop, $11.8 \mathrm{~m}$ for middle age crop, and $7.9 \mathrm{~m}$ for young crop (Mukalil 2012). Data collected from the field were the plot coordinates using global positioning system (GPS), diameter at the breast height (dbh), total height, canopy diameter, crown thickness, slope, aspect, and leaf area index (LAI) using fish-eye camera.

Total field plots analyzed in this study were 80 plots, where 20 plots belongs to jungle rubber, 30 plots belongs to rubber plantation, and the rest 30 plots belongs to oil palm plantation. For secondary forest, the study used the forest inventory data that had been collected by PT. REKI. The steps in in this research involving field plot measurement and processing, image processing and biomass estimation

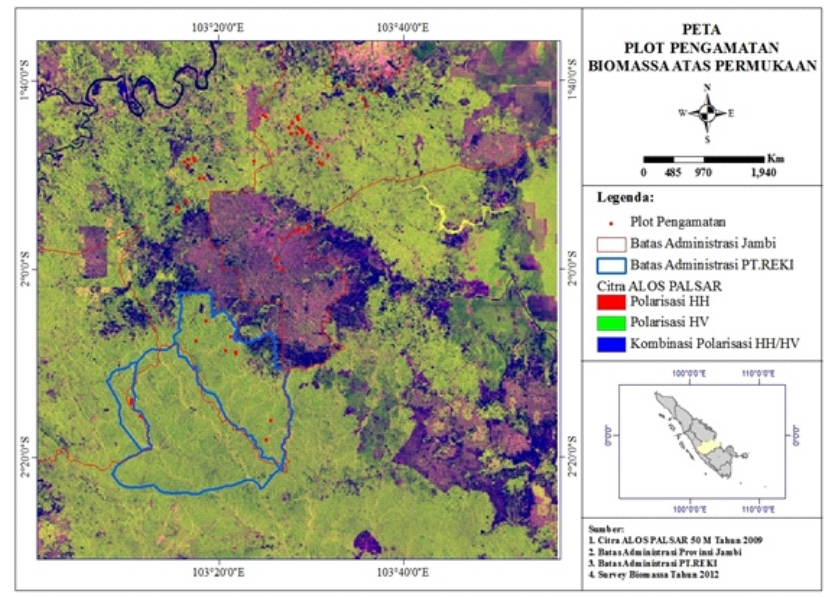

ALOS PALSAR image, RGB display:HH, HV, HH/HV

Figure 1 Study area and distribution of sample plots over transition ecosystem. 
model developed (Figure 2).

Biomass estimation of jungle rubber and secondary forest Prior to biomass estimation, the correlation analysis was conducted to observe the relationship among variables from field measurement data. Stand biomass was estimated using allometric equation based on wood density of the tree measure in the plot. This study used the Equation [1] of Ketterings et al.(2001) as follows:

$$
Y=0.01 \rho D^{2.62}
$$

note: $Y=$ above ground biomass $\left(\mathrm{kg}\right.$ tree $\left.^{-1}\right)$

$\rho=$ wood density $\left(\mathrm{g} \mathrm{cm}^{-3}\right)$

$D=$ diameter at the breast height $(\mathrm{cm})$

Biomass estimation for rubber and oil palm plantation Field data estimation was conducted to obtain the amount of above ground biomass in selected plots and Yulianti (2009).

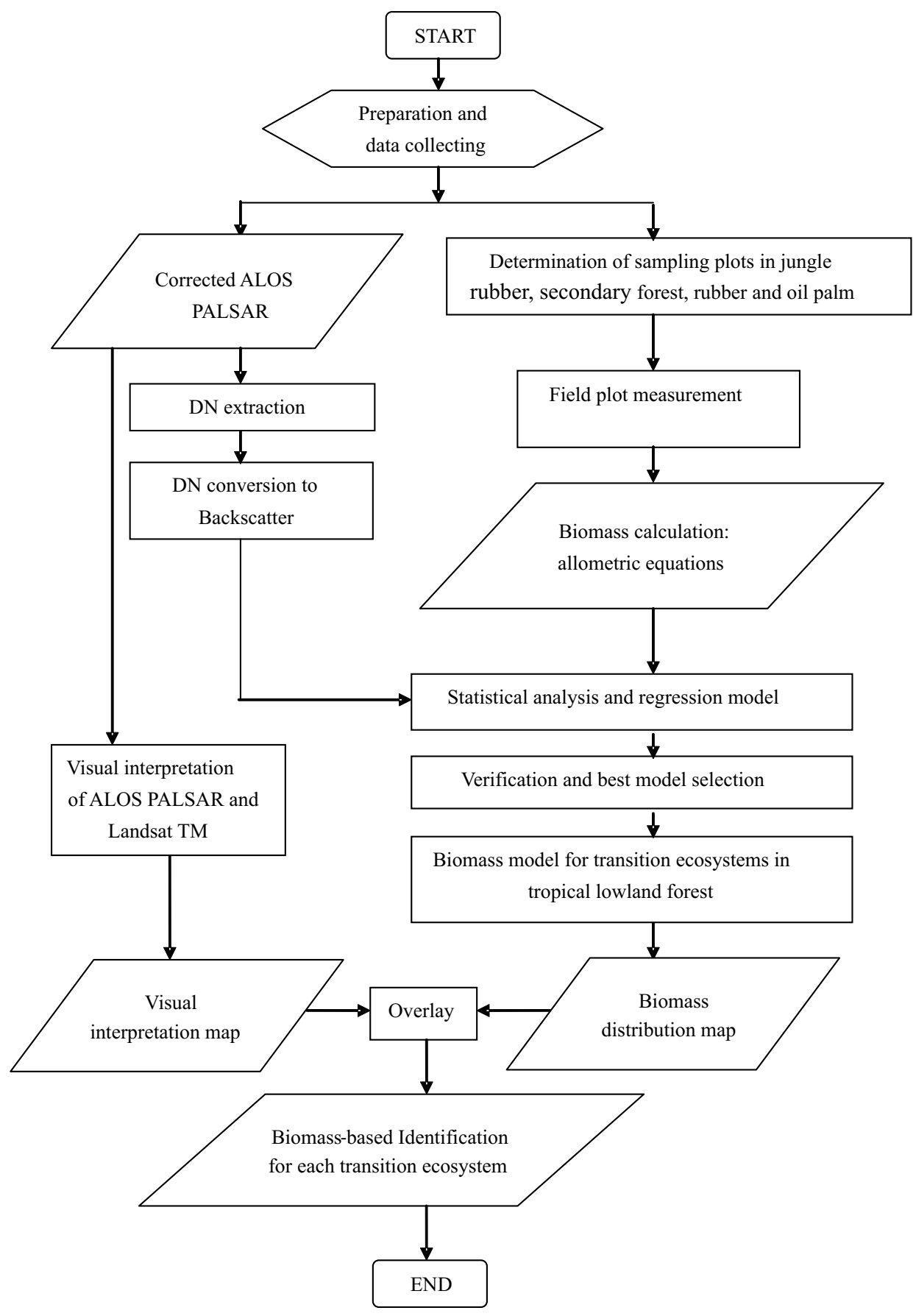

Figure 2 Biomass estimation based on ALOS PALSAR and field inventory. 
Alometric equation for rubber was using Yulyana 2005, as shown in Equation [2]:

$$
W=0.0124\left(D^{2}\right)^{0.2444}
$$

note:

$$
W=\text { above ground biomass }\left(\mathrm{t} \mathrm{ha}^{-1}\right)
$$$$
D=\text { diameter at the breast height (m) }
$$

For oil palm, the biomass was estimated using Yuliani (2009) as shown in Equation [3]:

$$
W=2.14 \exp ^{-5}\left(D^{1.51} H^{1.33}\right)
$$

note :

$$
\begin{aligned}
& W=\text { above ground biomass }\left(\mathrm{t} \mathrm{ha}^{-1}\right) \\
& D=\text { diameter at the breast height }(\mathrm{m}) \\
& H=\text { total height }(\mathrm{m})
\end{aligned}
$$

Image processing Prior to further analysis, there were 2 steps of image pre-processing applied namely spectral and spatial enhancement. In spectral enhancement, the addition of one band as the result of ratio $\mathrm{HH}$ to HV was applied. Spatial enhancement was performed using speckle suppression technique with Sigma Lee filter. Kernel sizes used were $3 \times 3,5 \times 5$, and $7 \times 7$. Furthermore, the conversion of digital number (DN) of ALOS PALSAR imagery was done using equation [4] found by Shimada et al. (2009).

$$
N R C S=10 \log 10\left(D N^{2}\right)-C F
$$

note:

$$
\begin{aligned}
& N C R S=\text { normalized radar cross section }(\text { in } \mathrm{dB}), \\
& D N=\text { digital number } \\
& C F \quad=\text { calibration factor }=83 .
\end{aligned}
$$

The display of image composite was using RGB display of $\mathrm{HH}, \mathrm{HV}, \mathrm{HH} / \mathrm{HV}$ bands to give better visualization. $\mathrm{HH}$ is the polarization of the horizontal backscattered received, meanwhile $\mathrm{HV}$ is the polarization of vertical backscattered received by radar sensor.

Visual interpretation of transition ecosystem types ALOS PALSAR and LANDSAT TM imagery were visually interpreted to identify the types of transition ecosystem over the study area. The result of visual interpretation was then used to estimate biomass by overlaying the map of biomass with land cover map developed. The supporting imageries used in this process were LANDSAT TM having the same year of acquisition with ALOS PALSAR image. The classification was aided by the land cover in year of 2009 map developed by Ministry of Forestry Republic of Indonesia, coupled with land cover derived in this study using LANDSAT TM interpretation.

\section{Results and Discussion}

Correlation of stand variables of transition ecosystem Correlations among stand variables were examined using Pearson correlation statistics test. The correlation of secondary forest, jungle rubber, rubber, and oil palm are summarized in Table 1, 2, 3, and 4 respectively. Stand variables of secondary forest which have strong relationship were diameter, basal area, biomass and tree volume. Diameter and biomass has positive correlation value of 0.88 which indicates the strong correlation between them. This means that the stand can be characterized either by their own diameter of biomass distribution. Instead of diameter, the biomass calculation employed was wood density as derived from allometric equation found by Ketterings et al. (2001).

Correlations for stand variables (Table 2) in jungle rubber also show strong correlation between diameter, numbers of tree per hectare, basal area, biomass and tree volume. Diameter and biomass show a good correlation with the value of 0.61 . The correlation value between diameter and biomass in jungle rubber is lower than that of in the secondary forest. This might be due to the stand structure of jungle rubber that is relatively homogenous both in tree size and tree species. In jungle rubber, the stand is dominated by rubber tree (Gouyon et al. 1993; Dove 1994). and the biomass calculation was derived from Ketterings allometric equation that also employed wood density.

Correlations among variables in rubber plantation (Table 3 ) were relatively better than both secondary forest and rubber jungle, where good correlation among diameter, total height, crown diameter, crown thickness, and basal area were found. There was strong correlation between diameter and biomass with the correlation value of 0.93 and followed by volume and basal area. This finding is also in line with the study of Mukalil (2012) who found the strong correlation of plant variables in jungle rubber between diameter and biomass as 0.95 , and between volume and basal area. In case of oil palm plantation (Table 4), the correlation among plant variables do not show strong correlation. The strong correlations were shown between diameter and biomass, and also between diameter and basal area.

Strong correlation among variables indicates the linear relationship among variables, which means the variance of one variable is able to explain other variable variances (Mattjik \& Sumertajaya 2006). Therefore, some stand or plant variables could explain its effect on backscatter of ALOS PALSAR in transition ecosystem under study.

Relationship between biomass and backscatter Based on the backscatter magnitude of polarization $\mathrm{HH}$ and $\mathrm{HV}$, and $\mathrm{HH} / \mathrm{HV}$ ratio that have been related to field biomass in four ecosystem types, logarithmic-shaped scatter diagrams were obtained. From $\mathrm{HH}$ and $\mathrm{HV}$ polarization and biomass, the value of $R^{2}$ was 0.235 and 0.523 respectively, and for $\mathrm{HH} / \mathrm{HV}$ ratio was 0.122 . Low correlation between backscatter and biomass mainly due to variation of vegetation properties in various transition ecosystem observed and the saturation (asymptote) problem of backscatter.

From observed polarization, HV shows a good relationship with field biomass indicated by its higher correlation among others. It also found that there was biomass saturation even though the backscatter magnitude increased. In this study, it showed that the saturation occurred at 100 tha $^{-1}$. Saturation is a common problem found in image processing, in accordance to the study of Luckman et al. 1997; Austin et al. 2003; Morrel et al. 2011; and Jaya et al. 2013.The study in eucalyptus plantation was conducted by Austin et al. (2003) using radar image and the saturation was about $600 \mathrm{t} \mathrm{ha}^{-1}$. Jaya et al. 2013 reported the saturation over dryland forest using ALOS PALSAR in Central Kalimantan was $300 \mathrm{t} \mathrm{ha}^{-1}$, meanwhile Morrel et al. 2011 found the saturation using ALOS PALSAR for oil palm and forest in Sabah Malaysia was 80 ton $\mathrm{ha}^{-1}$. Saturation using SAR image of $60 \mathrm{t} \mathrm{ha}^{-1}$ in Amazon tropical forest was reported by Luckman et al. (1997).

HV polarization was sensitive to biomass density, especially to assess above ground biomass in lowland and flat terrains (Wijaya 2009). HV polarization is also sensitive to be used to estimate the biomass over less complex 
Table 1 Correlation among stand variables of secondary forest

\begin{tabular}{lrrrrrrr}
\hline Stand variables & Diameter & $\mathrm{N} \mathrm{ha}^{-1}$ & \multicolumn{1}{c}{ BA } & \multicolumn{1}{c}{ Biomass } & \multicolumn{1}{c}{ TT } & \multicolumn{1}{c}{ Volume } & \multicolumn{1}{c}{ TBC } \\
\hline Diameter & 1.00 & -0.64 & 0.97 & 0.88 & 0.49 & 0.94 & 0.34 \\
$\mathrm{~N} \mathrm{ha}^{-1}$ & & 1.00 & -0.49 & -0.40 & -0.41 & -0.45 & -0.19 \\
$\mathrm{BA}$ & & & 1.00 & 0.94 & 0.43 & 0.97 & 0.33 \\
Biomass & & & & 1.00 & 0.36 & 0.92 & 0.30 \\
$\mathrm{TT}$ & & & & & 1.00 & 0.55 & 0.69 \\
Volume & & & & & 1.00 & 0.43 \\
TBC & & & & & & 1.00 \\
\hline BA = basal area, $\mathrm{TT}=$ total height, $\mathrm{TBC}=$ free trunk of height, correlation value is Pearson correlation test.
\end{tabular}

Table 2 Correlation among stand variables of jungle rubber

\begin{tabular}{lcrrrc}
\hline Stand variables & Diameter & $\mathrm{N} \mathrm{ha}^{-1}$ & $\mathrm{BA}$ & \multicolumn{1}{c}{$\mathrm{TT}$} & Biomass \\
\hline Diameter & 1.00 & -0.82 & 0.96 & 0.35 & 0.61 \\
$\mathrm{~N} \mathrm{ha}^{-1}$ & & 1.00 & -0.76 & -0.26 & -0.14 \\
$\mathrm{BA}$ & & & 1.00 & 0.30 & 0.62 \\
$\mathrm{TT}$ & & & & 1.00 & 0.25 \\
Biomass & & & & & 1.00 \\
\hline $\mathrm{BA}=$ basal area, $\mathrm{TT}=$ total height. & & & &
\end{tabular}

Table 3 Correlation among crop variables of rubber plantation

\begin{tabular}{lclllllc}
\hline Plant variables & Diameter & TT & CT & CD & Biomass & BA & Volume \\
\hline Diameter & 1.00 & 0.69 & 0.65 & 0.71 & 0.93 & 0.72 & 0.73 \\
TT & & 1.00 & 0.77 & 0.66 & 0.53 & 0.97 & 0.90 \\
CT & & & 1.00 & 0.71 & 0.50 & 0.71 & 0.65 \\
CD & & & & 1.00 & 0.59 & 0.62 & 0.58 \\
Biomass & & & & 1.00 & 0.62 & 0.68 \\
BA & & & & & & 1.00 & 0.98 \\
Volume & & & & & & & 1.00 \\
\hline
\end{tabular}

$\mathrm{TT}=$ total height, $\mathrm{CT}=$ crown thickness, $\mathrm{CD}=$ crown diameter, $\mathrm{BA}=$ basal area.

Table 4 Correlation among plant variables of oil palm plantation

\begin{tabular}{lccccccc}
\hline Plant variables & Diameter & TT & CT & CD & Frond & Biomass & BA \\
\hline Diameter & 1.00 & 0.35 & 0.33 & 0.37 & 0.33 & 0.62 & 0.96 \\
TT & & 1.00 & 0.57 & 0.59 & 0.11 & 0.91 & 0.32 \\
CT & & 1.00 & 0.48 & 0.38 & 0.52 & 0.31 \\
CD & & & 1.00 & 0.05 & 0.54 & 0.26 \\
Frond/Pelepah & & & & 1.00 & 0.19 & 0.29 \\
Biomass & & & & & 1.00 & 0.64 \\
BA & & & & & & 1.00 \\
\hline
\end{tabular}

$\mathrm{TT}=$ total height, $\mathrm{CT}=$ crown thickness, $\mathrm{CD}=$ crown diameter, $\mathrm{BA}=$ basal area.

vegetation landscape as concluded by Luckman et al. 1997; Morrel et al. 2011, and Jaya et al. 2013. In this study, the secondary forests are logged over forests. Furthermore, models examined in this study confirmed that HV polarization is sensitive to biomass content. The selection of polarization being used in developing biomass model from radar backscatter is a critical factor (Jaya et al. 2013). In this study, biomass estimation model was developed based on its own model derived from backscatter and field biomass due to that the nature of model is site specific and the model obtained then will be used as one of discriminant to identify transition ecosystem under study.

Biomass regression model and validation Prior to develop models from all transition ecosystem types, each regression equation was tested using the variance of regression model with covariance analysis. The grouping of 
using all transition ecosystem (secondary forest, jungle rubber, rubber plantation and oil palm plantation) provided F-calculation (F-calc) of 1.03 , which was smaller than Ftable (2.71) at confidence level of $5 \%$. This value implied that the grouping factor did not give significant role and did not have significantly different model, therefore, regression models met the requirement to be used altogether to develop biomass model for all transition ecosystem types under study.

The models examined in this study were linear, exponential, and polynomial model forms. Correlation between backscatter $\mathrm{HH}, \mathrm{HV}$, and $\mathrm{HH} / \mathrm{HV}$ and field biomass are illustrated in Figure 3. Initially, there were 72 models developed and examined. The study found that the increasing of filter size (speckle suppression) with the kernel size of $5 \times 5$ and $7 \times 7$ did not improve determination coefficient, therefore, 36 models were selected that would be tested for the best model. Best model selection was identified on the basis of determination coefficient $\left(R^{2}\right)$ and $p$-values each model being developed. All selected models are statistically significant effect to estimate biomass using the independent variable of

\section{HH vs Biomassa}
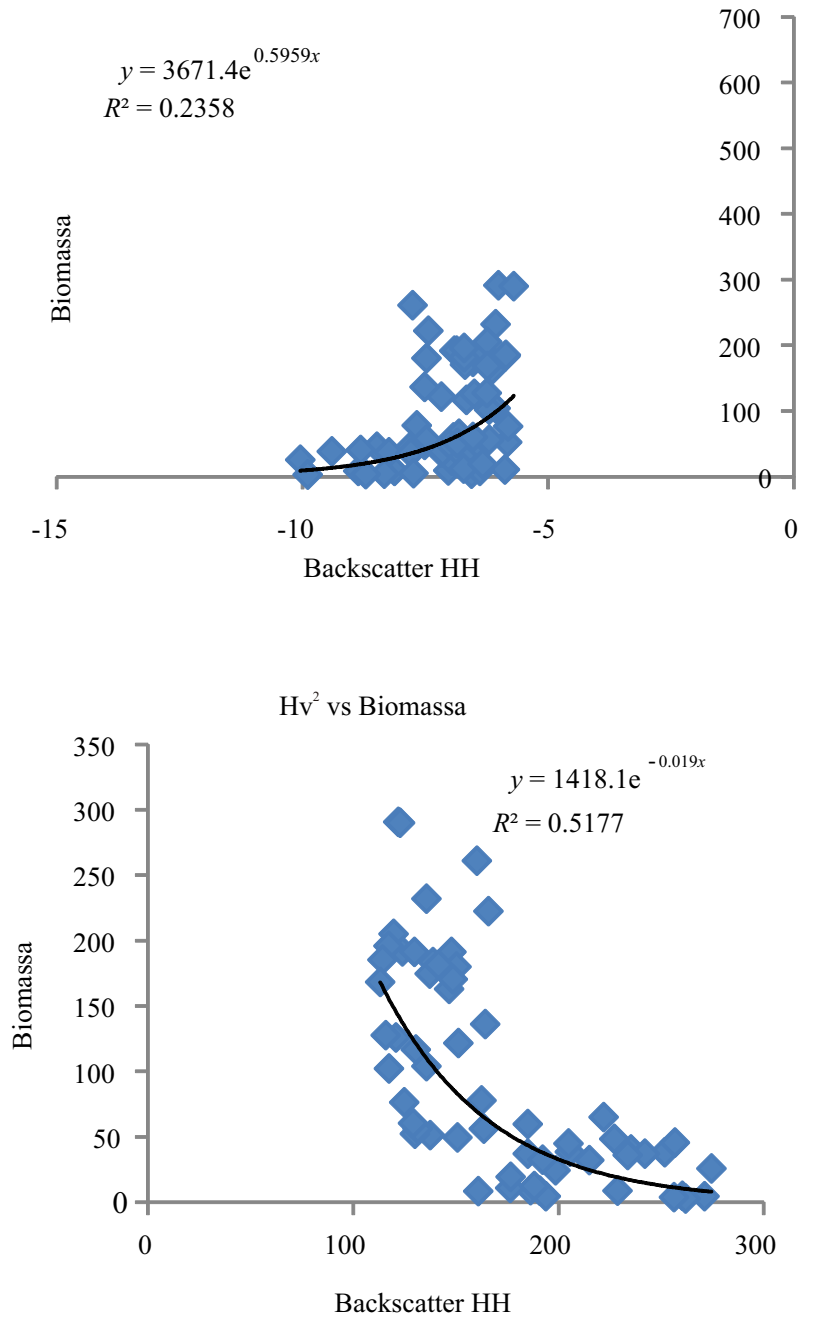

backscatter of $\mathrm{HH}, \mathrm{HV}$, ratio of $\mathrm{HH} / \mathrm{HV}, \mathrm{HH}^{2}, \mathrm{HV}^{2}$, and squared ratio $(\mathrm{HH} / \mathrm{HV})^{2}$. Determination coefficient value provided by the models is ranging from $41.71 \%$ to $52.3 \%$, with the correlation coefficient between 0.65 and 0.75 and coefficient of regression have p-values less than $5 \%$. The selected models should also consider the simplicity for practical and the ease of use purposes (Jaya et.al 2013). Models selected are presented in Table 5.

Models developed were validated using mean deviation (MD), agregative deviation (AD), root mean square error (RMSE), Bias (e), and $\chi^{2}$ test measures. The validation test was conducted using 30 data plots derived from inventory plots consisted of 27 plot collected by PT. REKI and 3 plots from field measurement data within transition ecosystems collected by authors. Verification plots were selected using systematic sampling with random start.

The validation values shows that the examined models provided good biomass estimation. All models show very low $\mathrm{AD}$ in a range of -0.01 to 0.05 , belong within the range of -1 to +1 , therefore, the models are acceptable. Mean
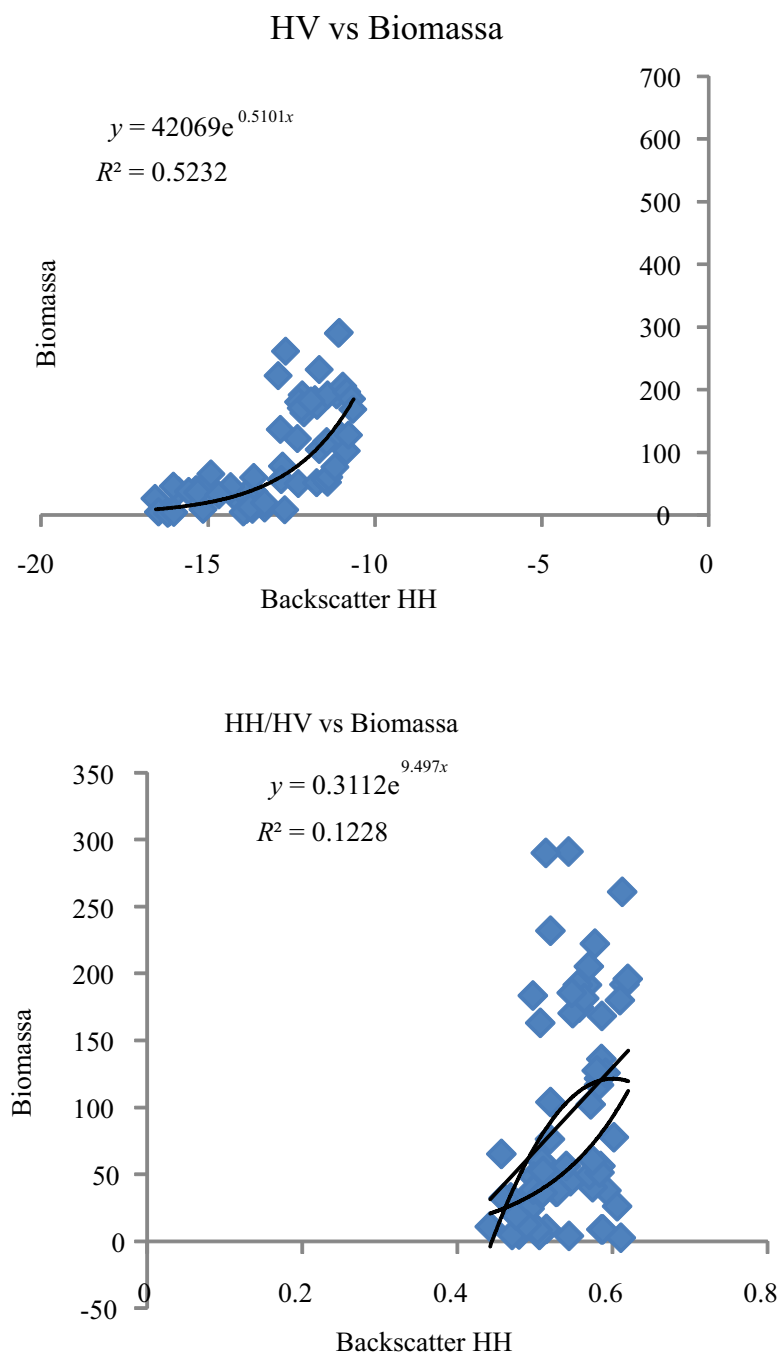

Figure 3 Biomass estimation model using (a) HH (b) $\mathrm{HV}$ (c) $\mathrm{HV}^{2}$ (d) HH/HV. 
Tabel 5 Selected model based on $R^{2}$ and $p$-value.

\begin{tabular}{lcllllc}
\hline Images & Buffer & No & Equation & $R^{2}$ & $r$ & $p$-value (Sig) \\
\hline Raw images & $1 \times 1$ & 1 & $\mathrm{AGB}=42.069 \exp (0.510 \mathrm{HV})$ & 0.523 & 0.72 & 0.000 \\
& $3 \times 3$ & 2 & $\mathrm{AGB}=58.018 \exp (0.534 \mathrm{HV})$ & 0.435 & 0.66 & 0.000 \\
& $3 \times 3$ & 3 & $\mathrm{AGB}=1.646 \exp \left(-0.02 \mathrm{HV}^{2}\right)$ & 0.425 & 0.65 & 0.000 \\
Speckle Supression & $1 \times 1$ & 4 & $\mathrm{AGB}=54.432 \exp (0.528 \mathrm{HV})$ & 0.514 & 0.72 & 0.000 \\
Kernel 3×3 & $1 \times 1$ & 5 & $\mathrm{AGB}=1.610 \exp \left(-0.02 \mathrm{HV}^{2}\right)$ & 0.508 & 0.71 & 0.000 \\
& $3 \times 3$ & 6 & $\mathrm{AGB}=1.701 \exp \left(-0.02 \mathrm{HV}^{2}\right)$ & 0.417 & 0.65 & 0.000 \\
\hline
\end{tabular}

deviations are also in the range of $3.25 \%$ and $10.88 \%$. Good models should have MD less than 10\% (Spurr 1952). Acceptable models also consider small value of bias resulted in the range of 3.04 and 11.77. The $\chi^{2}$ test determined the acceptable selected models if $\chi^{2}$ calculated were larger than $\chi^{2}$ table. It showed that there is no significantly different between estimated biomass and actual biomass. Based on the simplicity and the easiness to use, and polarization sensitive to biomass, the selected models to map the biomass under study were $\mathrm{AGB}=42,069 \exp (0.510 \mathrm{HV})$ and, $\mathrm{AGB}=1,610$ $\exp \left(-0.02 \mathrm{HV}^{2}\right)$.

Biomass-based mapping in visual identification of transition ecosystem Selected biomass estimation models were then was used to map the biomass distribution of transition ecosystem within the study area. In Figure 5, visually there was significant different between secondary forest and oil palm plantation which displayed indifferent color. The big oil palm plantation is commonly the intensive plantation managed by private company, while small oil palm pantation in transmigration area is owned by community at Muaro Jambi and Batanghari Regency.

In Figure 4, average biomass based on field study showed the pattern of biomass content in transition ecosystem. Oil palm and rubber plantation have relatively low biomass content rather than jungle rubber and secondary forest. Rubber plantation in the study area shows low biomass content due to the age of planting for rubber plot mostly in less than 10 years. The biomass content for rubber and oil palm plantation will increase as well as the age of the crop increases. Meanwhile, between secondary forest and jungle rubber are almost the same in biomass content. Jungle rubber is land cover that has similarities with secondary forest (Gouyon et al. 1993 \& Dove 1994) having stand structure similar to natural forest with high diversity of tree species dominated by rubber (Hevea brasiliensis). Differences of biomass content in each ecosystem types exist due to the differences of ecological factors. Masripatin et al. (2010) mentioned that the range of biomass in every type of ecosystems are different as follows, for logged-over secondary forest in Malinau and Nunukan Regency, East Kalimantan has biomass content ranging from 343.6 to 498.4 $\mathrm{t} \mathrm{ha}^{-1}$, forest with agroforestry system has biomass content of $182 \mathrm{tha}^{-1}$, bush and shrubs with the biomass content of $38.8 \mathrm{t}$ $\mathrm{ha}^{-1}$. Mukalil (2012) found that average biomass content of oil palm and rubber plantation are $25.89 \mathrm{t} \mathrm{ha}^{-1}$ and $6.94 \mathrm{t} \mathrm{ha}^{-1}$, respectively.

From biomass distribution map depicted in Figure 5, secondary forest ecosystem commonly adjacent to oil palm plantation have relatively higher biomass content than oil palm plantation. Transition from forest into agricultural land such as mixed field and monoculture plantation are moving towards Jambi City. Rubber and dry field agriculture historically were cultivated by community since the early of twentieth century (Gouyon et al. 1993), therefore, the area of this agricultural systems are located close to the settlement. Classes derived from biomass distribution then were used as a discriminant to identify transition ecosystem in Jambi Province, from Harapan rainforest to Jambi City.

In transition area of secondary forest in the north-east of PT.REKI, there were significant changes of biomass. The fuzzy border and access close to the road has triggered landuse change from forest into agricultural systems such as dry field agricultural and establishment oil palm plantation. This also become the major source of conflicts between the forest restoration concession holder and the people who enclave the area inside.

Based on visual interpretation to classify the land cover of study area, the problems of mixed pixel and spatial uncertainty were emerged. The source of mixed pixel in visual classification was due to slightly changes of landcover area. For example, changes from rubber plantation or old shrubs to oil palm have caused mixed classes of oil palm and bareland (land clearing) in relatively small area but randomly distributed. Recently, there is a trend of landcover changes from tropical lowland forest into oil palm, secondary forest, jungle rubber, rubber plantation, and other land use.

Ambiguity or spatial uncertainty could be caused by uncertainty of the methods in landscape analysis like spatial and temporal heterogenity and also ambiguity in classification (Hou et al. 2012). In case of transition ecosystem, the source of uncertainty mainly due to spatial pattern or landscape structure from natural condition (wilderness) to settlement area. It is also affected by relationship between pattern and process in landscape, process and changes, human activity and landscape pattern (Hou et al. 2012).

Visual interpretation of ALOS PALSAR to classify land cover within study area were supported using land cover map published by ministry of forestry at the same year of acquisition. LANDSAT TM imagery was also involved to aid visual classification. Furthermore, the result of the classification was overlaid with biomass map derived from the model developed using ALOS PALSAR to identify the types of transition ecosystem based on biomass. The result of 


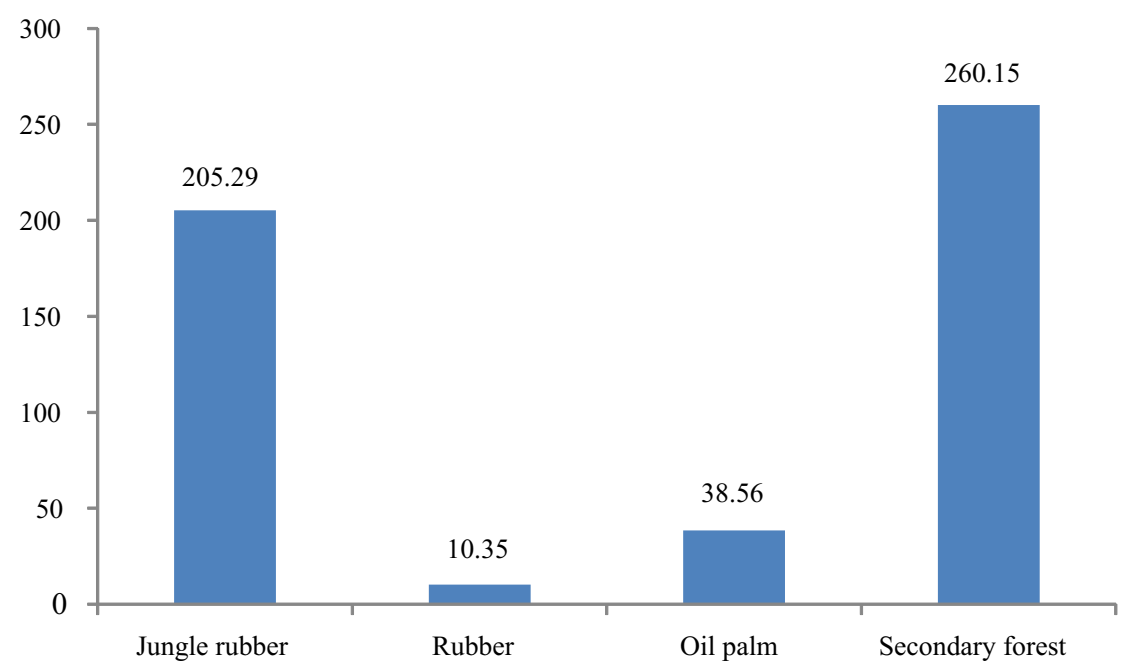

Figure 4 Field biomass in transition ecosystem types.

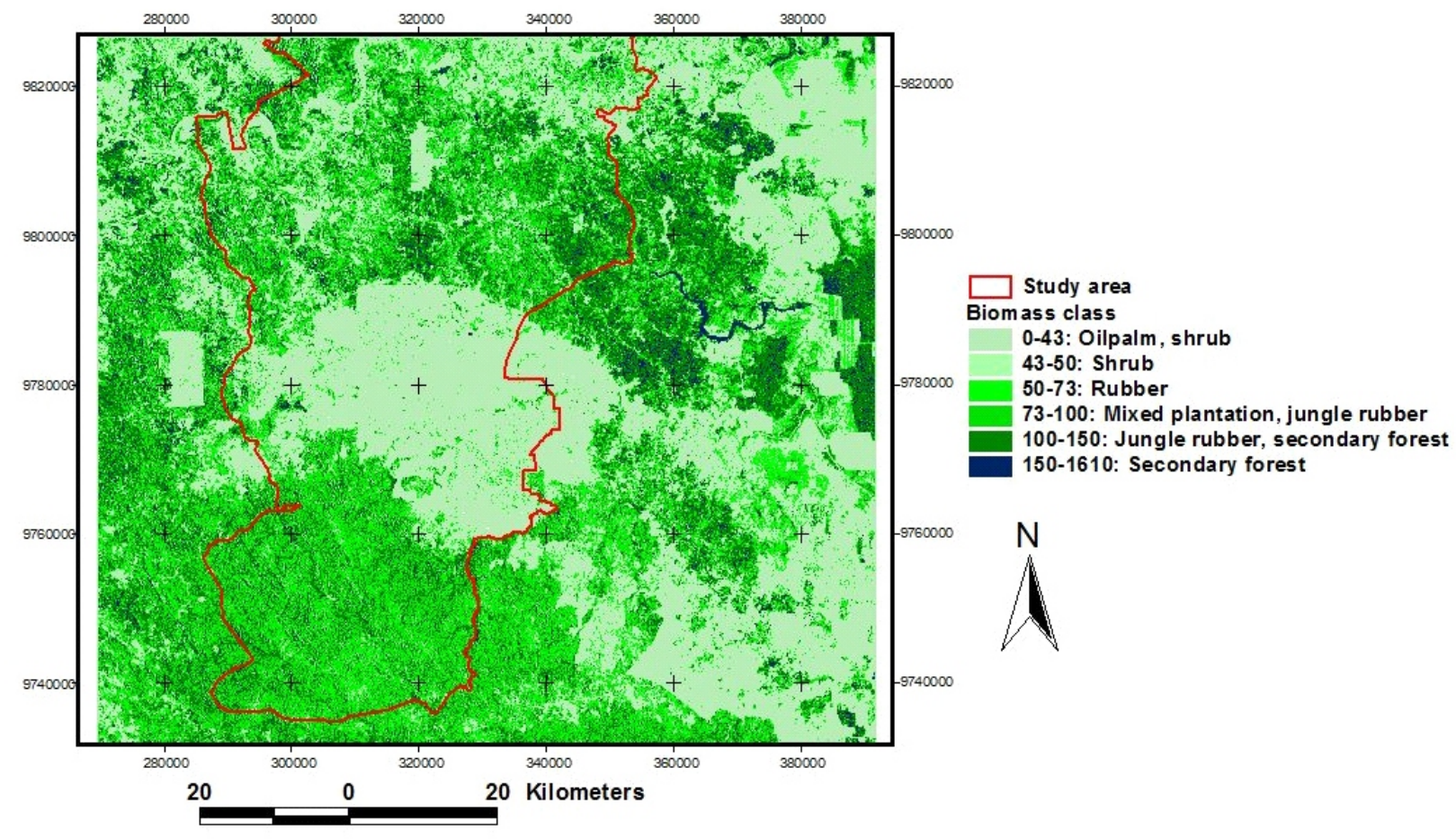

Figure 5 Biomass distribution of transition ecosystem in Jambi Province.

biomass for each type of transition ecosystems was then summarized in Table 6. The minimum, maximum, and mean values were varied for each class and also there were some overlapping value. The minimum value showed the lowest biomass content and it belonged to lowest vegetation covered in the area. Pixel based mapping has limitation of high level of spatial uncertainty. Mixed pixels is the common problem arisen in classification of remotely sensed imageries both in low and medium resolution (Li et al. 2011; Hou et al. 2012).

Figure 7 shows the overlapping biomass value among classes. There were mixed pixels in each class and consequently, the range of biomass content varied in its minimum and maximum value. Based on the mean value, oil palm had the lowest biomass content among transition ecosystem types found. Ambiguity or uncertainty might be occurred between old jungle rubber and secondary forest because the similarity of complex structure, meanwhile young jungle rubber would have ambiguity with monoculture rubber (rubber plantation) because the numbers of rubber trees are higher than other forest tree species. Transition pattern were from secondary forest in Harapan rainforest (PT. REKI) to agricultural 
Table 6 Biomass estimation $\left(\mathrm{t} \mathrm{ha}^{-1}\right)$ based on visual interpretation of ALOS PALSAR

\begin{tabular}{llrrc}
\hline Classes & Min & \multicolumn{1}{c}{ Max } & Mean & SD \\
\hline Secondary forest & 98.13 & 231.47 & 164.80 & 66.67 \\
Jungle rubber & 46.90 & 160.61 & 103.75 & 56.85 \\
Rubber & 33.65 & 109.55 & 71.60 & 37.95 \\
Oil palm & 23.46 & 61.41 & 42.43 & 42.43 \\
Mixed plantation & 31.90 & 118.71 & 75.30 & 43.41 \\
Bush and shrub & 19.23 & 70.41 & 44.82 & 25.59 \\
\hline
\end{tabular}

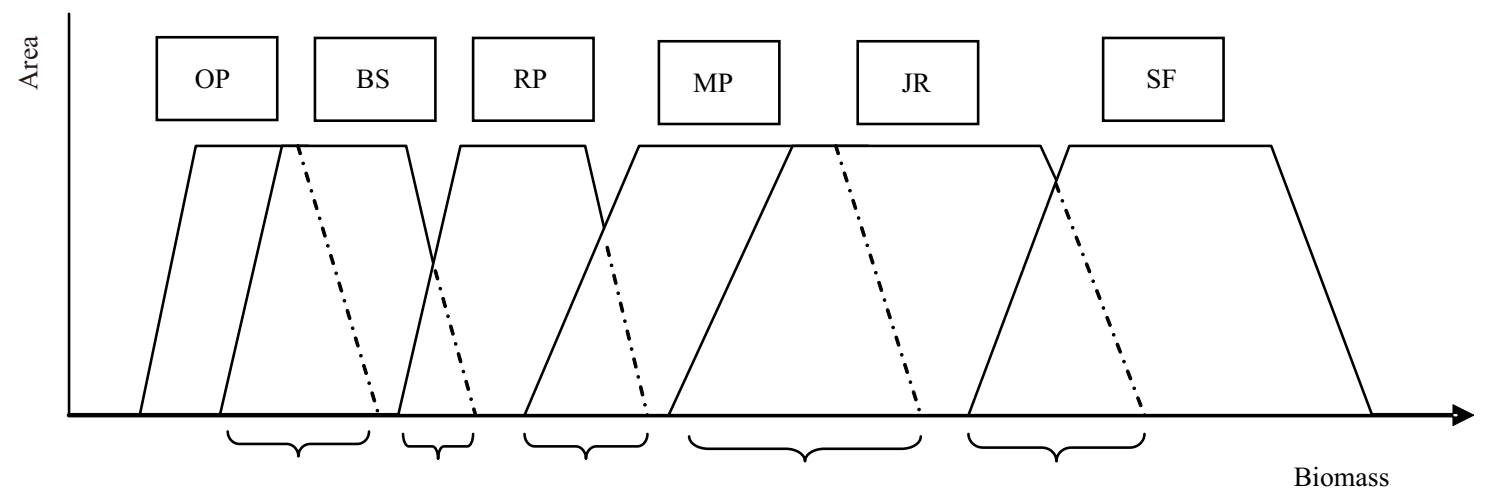

Figure 7 Fuzzyness in biomass content for each class in transition ecosystem.

transformation system, oil palm in large area, and become dry field and shrubs. Rubber monocultures are widely distributed over the regencies and tend to change into oil palm with scattered pattern in small areas, particularly along the road towards Jambi City.

\section{Conclusion}

ALOS PALSAR imagery could be used to develop biomass estimation model in transition ecosystem which has been transformed from secondary forest into agricultural system and other landuse. Cross polarization $\mathrm{HV}$ is more sensitive than $\mathrm{HH}$ to estimate biomass in transition ecosystem. Acceptable models are $\mathrm{AGB}=42,069$ exp $(0.510 \mathrm{HV})$ and with using filtering with the equation of $\mathrm{AGB}$ $=1,610 \exp \left(-0.02 \mathrm{HV}^{2}\right)$. Biomass spatial distribution derived from the model being developed could be used to identify transition ecosystem by overlaid it with landcover resulted from visual interpretation. Biomass distribution had problems of spatial uncertainty because the classes is mainly derived from visual interpretation. Biomass-based transition ecosystem identification enriched the existing methods based on ecological approach to identify ecosystems. Furthermore, it needs to develop methods to reduce the spatial uncertainty and mixed problems and fuzzyness.

\section{References}

Abdullah L. 2010. Model dynamic of forest and land use change and carbon trade scenario in Jambi [thesis]. Bogor: Graduate School of Bogor Agricultural University.
Austin JM, Mackey BG, Van Niel KP. 2003. Estimating forest biomass using satellite radar: an exploratory study in a temperate Australian eucalyptus forest. Forest Ecology and Management 176: 575-583. http://dx.doi.org/10.1016/S0378-1127(02)00314-6.

Basuki TM. 2012. Quantifying tropical forest biomass [dissertation]. Netherlands: University of Twente.

Bergen MK, Dobson MC. 1999. Integration of remotely sensed Radar imagery in modeling and mapping of forest biomass and net primary production. Ecological Mode lling 122 : $257-274$. http://dx.doi.org/10.1016/S0304-3800(99)00141-6

Brown F, MartinelliLA, Thomas WW, Moreira MZ, Ferreira CAC, Victoria, RA.1995. Uncertainty in the biomass of Amazonian forests: an example from Rondonia, Brazil. Forest Ecology and Management 75:15-189. http://dx.doi.org/10.1016/03781127(94)03512-U.

Chambers JQ, Asner GP, Morton DC, Anderson LO, Saatchi SS, Espirito-Santo FDB, Palace M, Souza Jr C. 2007. Regional ecosystem structure and function: ecological insights from remote sensing of tropical forests. TRENDS in Ecology and Evolution 22(8): 414-423. http://dx.doi:10.1016/j.tree.2007.05.001.

Chen X, Vierling L, Rowell E, De Felice T. 2004. Using lidar and effective LAI data to evaluate IKONOS and Landsat 7ETM+ vegetation cover estimates in a 
Ponderosa pine forest. Remote Sensing of Environment 91: 14-26. http://dx.doi.org/10.1016/j.rse.2003.11.003.

Clark DA, Brown S, Kicklighter DW, Chambers JQ, Thomlinson JR, Ni J, Holland EA, 2001. Net primary production in tropical forests: an evaluation and synthesis of existing field data. Ecological Application 11(2): 371-384. http://dx.doi.org/10.1890/1051-0761 (2001)011[0371:NPPITF]2.0.CO;2.

Dove MR. 1994. Transition from native rubbers to Hevea brasiliensis (Euphorbiaceae) among Tribal Smallholders in Borneo. Economic Botany 48 (4):382-396. http://dx.doi.org/10.1007/BF02862233.

Elias, Wistara NJ. 2009. Method for estimation of tree carbon mass of Paraserianthes falcataria L Nielsenin community forest. Journal of Tropical Forest Management 15: 75-82.

Foody GM, Boyd DS,Cutler MEJ. 2003. Predictive relations of tropical forest biomass from Landsat TM data and their transferability between regions. Remote Sensing of Environment 85 (4): $463-474$. http://dx.doi.org/10.1016/S0034-4257(03)00039-7.

Geist H, Lambin E. 2001. What drives tropical deforestation? A meta-analysis of proximate and underlying causes of deforestation based on subnational case study evidence. LUCC Report Series 4. Belgium: University of Louvain.

Gouyon A, De Foresta H, Levang P. 1993. Does 'jungle rubber' deserve its name? An analysis of rubber agroforestry systems in southeast Sumatra. Agroforestry Systems $\quad 22: 181-206$. http://dx.doi.org/10.1007/BF00705233.

Hou Y, Burkhard B, Mueller F. 2012. Uncertainties in landscape analysis and ecosystem service assessment. Journal of Envoironmental Management xxx 2012: 1-15. http://dx.doi.org/10.1016/j.jenvman.2012.12.02.

Houghton RA, Lawrence KT, Hackler JL, Brown S. 2001. The spatial distribution of forest biomass in the Brazilian Amazon: A comparison of estimates. Global Change B i o l o g y 7 ( 7 ) : $731-746$. http://dx.doi.org/10.1046/j.1365-2486.2001.00426.x.

[IPCC] International Panel on Climate Change. 2006. Guidelines for National Greenhouse Gas Inventories: Volume 4: Agriculture, Forestry and Other Land Use.

Jaya INS, Agustina TL, Saleh MB, Shimada M, Kleinn C, Fehrmann L. 2013. Above ground biomass estimation of dry land tropical forest using ALOS PALSAR in Central Kalimantan, Indonesia. In:Proceedings of the $3 \mathrm{rd}$ International DAAD Workshop Forests in Climate Change Research and Policy: The Role of Forest Management and Conservation in a Complex International Setting. $28^{\text {th }}$ November to 2 nd December 2012, Dubai and Doha. Cuvellier Verlag Göttingen.
[JICA-FAHUTAN IPB] Japan International Cooperation Agency dan Fakultas Kehutanan IPB. 2011. Manual Penafsiran Citra ALOS-PALSAR untuk Mengenali Penutupan Lahan/Hutan di Indonesia. Bogor: Fakultas Kehutanan IPB.

Ketterings QM, Coe R, Noordwijk MV, Ambagau Y, Palm CA. 2001. Reducing uncertainty in the use of allometric biomass equations of predicting aboveground tree biomass in mixed secondary forest. Forest Ecology and Management 146: 199-209. http://dx. doi.org/10.1016/S0378-1127(00)00460-6.

Li X, DuY, Ling F, Wu S, Feng Q. 2011. Using a sub-pixel mapping model to improve the accuracy of landscape pattern indices. Ecological Indicators 11:1160-1170. http://dx.doi:10.1016/j.ecolind.2010.12.016.

Lu D, Mausel P, Brondizio E, Moran E. 2004. Relationships between forest stand parameters and Landsat TM spectral responses in the Brazilian Amazon Basin. Forest Ecology and Management 198(1-3): 149-167. http://dx.doi.org/10.1016/j.foreco.2004.03.048.

Lu D. 2005. Above ground biomass estimation using Landsat TM data in the Brazilian Amazon. International Journal of Remote Sensing 26(12): 2509-2525. http://dx.doi.org/10.1080/01431160500 142145 .

Lu D. 2006. The potential and challenge of remote sensingbased biomass estimation. International Journal of Remote Sensing 27(7):1297-1328. http://dx.doi.10.1080/01431160500486732.

Lucas RM, Cronin N, Lee A, Moghaddam M, Witte C, Tickle P. 2006. Empirical relationships between AIRSAR backscatter and LiDAR-derived forest biomass, Queensland, Australia, Remote Sensing of Environment 100 : $407-425$. http://dx.doi.org/10.1016/j. rse.2005. 10.019.

Luckman A, Baker J, Kuplich TM, Yanasse CDF, Frery AC. 1997. A study of the relationship between Radar backscatter and regenerating tropical forest biomass for spaceborne SAR instruments. Remote Sensing $E n v i r o n m e n t \quad 60: \quad 1-13$. http://dx.doi.org/10.1016/S0034-4257(96)00121-6.

Mattjik AA, Sumertajaya IM. 2006. Perancangan Percobaan dengan Aplikasi SAS dan Minitab. Jilid I. Bogor: IPB Press.

[MoF] Ministry of Forestry. 2012. Statistik Kehutanan Indonesia 2011. Jakarta: Kementerian Kehutanan Direktoral Jendral Planalogi Kehutanan.

Morrel AC, Saatchi SS, Alhi Y, Berry NJ, Banin L, Burslem D, Nilus R, Ong RC. 2011. Estimating aboveground biomass in forest and oil palm plantation in Sabah, Malaysian Borneo using ALOS PALSAR data. Forest Ecology and Management 262: 


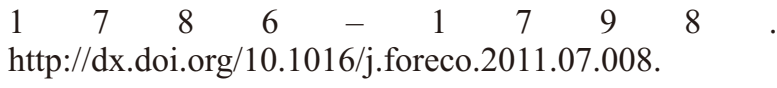

Mukalil. 2012. Study on the backscatter characteristics of ALOS PALSAR having spatial resolution of 50 meters and 12.5 meters within rubber and oil palm plantations [thesis]. Bogor: Graduate School of Bogor Agricultural University.

Masripatin, Ginoga K, Pari G, DharmawanWS, Siregar CA. 2010. Cadangan Karbon pada berbagai Tipe Hutan dan Jenis Tanaman di Indonesia. Bogor: Pusat Penelitian dan Pengambangan Perubahan Iklim dan Kebijakan.

Spurr SH. 1952. Forest Inventory. NewYork: The Ronald Press Company, Inc.

Steininger M. 2000. Satellite estimation of tropical secondary forest above-ground biomass: data from Brazil and Bolivia. International Journal of Remote Sensing 21(6-7):1139-1157.

Wang H, Hall CAS, Scatena FN, Fetcher N, Wu W, 2003. Modelling the spatial and temporal variability in climate and primary productivity across the Luquillo Mountains, Puerto Rico. Forest Ecology and Management 179:
69-94. http://dx.doi.org/10.1016/S03781127(02)00489-9.

Wijaya A. 2010. Complex land cover classifications and physical and physical properties retrieval of tropical forests using multi-source remote sensing [dissertation]. Germany: the Technische Universitat Bergakademie Freiberg.

Yulianti N. 2009. Carbon stock of peatland in oil palm agroecosystem of PTPN IV Ajamu, Labuhan Batu, North Sumatra. [thesis]. Bogor: Graduate School of Bogor Agricultural University.

Yulyana R. 2005. Carbon stock in the tapped rubber (case study in the nucleus smallholder estate, Pondok Kelapa Sub District Bengkulu Utara District)[thesis]. Bogor: Graduate School of Bogor Agricultural University.

Zeledon EB, Kelly NM. 2009. Understanding large-scale deforestation in southern Jinotega, Nicaragua from1978 to 1999 through the examination of changes in land use and land cover. Journal of Environmental Management. 90 : $2866-2872$. http://dx.doi.org/10.1016/j.jenvman.2008.03.016. 